ZOOLOGIA 31 (4): 361-369, August, 2014

http://dx.doi.org/10.1590/S1984-46702014000400007

\title{
Composition of bat assemblages (Mammalia: Chiroptera) in tropical riparian forests
}

\section{Elizabete Captivo Lourenço ${ }^{1,3}$, Luiz Antonio Costa Gomes², Michele da Costa Pinheiro1, Priscilla Maria Peixoto Patrício ${ }^{1} \&$ Kátia Maria Famadas ${ }^{1}$}

\author{
${ }^{1}$ Programa de Pós-graduação em Ciências Veterinárias, Laboratório de Artrópodes Parasitas, Departamento de Parasitologia \\ Animal, Instituto de Veterinária, Universidade Federal Rural do Rio de Janeiro. Rodovia BR 465, km 7, 23890-000 Seropédica, \\ Rio de Janeiro, Brasil. \\ 2 Programa de Pós-graduação em Biologia Animal, Laboratório de Mastozoologia, Universidade Federal Rural do Rio de Janeiro. \\ ${ }^{3}$ Corresponding author. E-mail: beteclouren1205@yahoo.com.br
}

\begin{abstract}
Various studies have focused on the richness and abundance of bats in tropical forests and how the composition of these forests affects bat assemblages, but there are few studies on the relationship of bats with riparian forests. The aim of this study was to ascertain the differences among bat assemblages of three riparian forest areas of the Tinguá region, state of Rio de Janeiro, Brazil. These areas were: I) an agricultural area (Takume); II) a reforested area in primary succession (Canavarro); and III) an area with late secondary vegetation (Tinguá Biological Reserve). Assessments of bat species composition in these areas may shed light on how anthropogenic modifications in riparian forests can influence local bat assemblages. Bats were captured with mist nets during 72 sampling nights. Total bat abundance was 1,511 individuals in 26 species. The three areas differed in their species composition. The Tinguá Biological Reserve was the richest area, Canavarro presented the lowest diversity and the highest abundance of individuals, and the evenness index was highest in Takume. The differences found in the composition and ecological indices indicate that bat assemblages have distinct characteristics in the three areas studied, with varied degrees of transformation and anthropization.

KEY WORDS. Anthropogenic modifications; Atlantic Forest; buffer zone; conservation; Tinguá Biological Reserve.
\end{abstract}

Various studies have focused on the richness and abundance of bats in tropical forests and how the composition of these forests affect bat assemblages (EsTRADA et al. 1993, ZANON \& Reis 2007, Bobrowiec \& Gribel 2010). However, there are few studies on the relationship of bats with riparian forests. The latter are relevant ecosystems in several respects, particularly for the conservation of water resources and biotic communities. They are found bordering rivers, streams and ponds, serving primarily as filters of pollutants and sediments that would otherwise reach the water (MARTINS 2001, LiMA \& ZAKIA 2001). Riparian forests also provide shelter and food for animals, and serve as ecological corridors, thus enabling maintenance of biological diversity (MarTins 2001, Lima \& ZaKia 2001, ArRiagaFLoREs et al. 2012). However, continued intervention and modifications of riparian forests and nearby water resources cause environmental damage, which in turn threaten the health and continuity of watercourses (MARTINS 2001, LIMA \& ZAKIA 2001, Arriaga-Flores et al. 2012).

The preservation and recuperation of riparian forests has been a matter of concern to the government and nongovernmental organizations in Brazil, because riparian forest strips are so important for the conservation and restoration of the biodiversity of many groups of animals and plants. In the same sense, trying to protect these forest areas from human intervention, the Brazilian government has made it a federal offense to tamper with them (Law 12,651 of 2012). In the state of Rio de Janeiro, a region of Atlantic forest remnant was delimited and converted into a protected area known as Tinguá Biological Reserve with the purpose of preserving the local water resources. This conservation unit has a surrounding buffer zone, where human activities are also subject to specific restrictions to minimize impact on the reserve (MMA 2006). Despite the legal restrictions on the buffer zone and riparian forests as a whole, riparian forests are still impacted, for instance when natural vegetation is removed for the cultivation of crops and establishment of pastures.

Several factors can contribute to the relevance of riparian forests in structuring bat assemblages. The floristic composition of riparian forests and their conservation status are directly related to the fauna of an area (Holloway \& BarCLAY 2000, Lima \& Zakia 2001, Cardoso-Leite et al. 2004, Camargo et al. 2009, Lourenço et al. 2010a, b, Costa et al. 2011, 2012). The different uses of riparian forests can partly determine their biodiversity and thus their local bat fauna (Fenton 1997, Williams et al. 2006). An assessment of the bat species composition in different types of riparian forest sheds light on how anthropogenic modifications 
can influence the local bat assemblage. Therefore, the aim of this study was to analyze whether there are differences in the bat assemblages of three riparian forest areas in the Tinguá region, state of Rio de Janeiro, Brazil: two areas inside the buffer zone of the Tinguá Biological Reserve (an agricultural and a reforested area in primary succession stage), and a third area inside the reserve characterized by late secondary vegetation. We expected to find the greatest richness, abundance and diversity of bats in the late secondary vegetation area, the least impacted area, followed by the reforested area. This hypothesis is based on prior knowledge that in environments where human pressure is stronger, species richness and diversity are lower (ODum \& BARRETT 2006, ReIs et al. 2006).

\section{MATERIAL AND METHODS}

This research was carried out in the Tinguá region, in the extreme northeast of the municipality of Nova Iguaçu, Rio de Janeiro, Brazil. Three areas within the limits of the Tinguá Biological Reserve and its buffer zone were investigated, with distances between areas varying from $3.10 \mathrm{~km}$ to $4.39 \mathrm{~km}$ (Fig. 1) and elevation ranging from 65 to $140 \mathrm{~m}$ above sea level.

Area 1. This agricultural area, designated Takume, lies in the buffer zone of the reserve $\left(22^{\circ} 35^{\prime} 16.53^{\prime \prime} S, 043^{\circ} 24^{\prime} 13.86^{\prime \prime} \mathrm{W}\right)$, and is characterized by the presence of guava (Psidium guajava L.) and banana trees (Musa paradisiaca L.). Area 1 is $15 \mathrm{~m}$ wide and $150 \mathrm{~m}$ long, perpendicular to the bank of Boa Esperança River, and includes leguminous species such as Brazilian fire tree (Schizolobium parahyba (Vell.)) and green Ipê (Cybistax antisyphilitica (Mart.) Mart) and an understory filled with Guinea grass (Panicum maximum Jacq.). It is bordered by peach palm trees (Bactris gasipaes Kunth). Various fruit trees surround the main residence, such as Malay rose apple (Syzygium malaccense (L.) Merr. \& L.M. Perry), cajá (Spondias lutea L.) and papaya (Carica papaya L.). Domestic animals such as dogs and chickens, and occasionally horses and cattle are also present.

Area 2. This area is located along the Ana Felícia River and was designated Canavarro. It is characterized as a reforested area in primary succession and is also located in the reserve's buffer zone $\left(22^{\circ} 36^{\prime} 50.69^{\prime \prime} \mathrm{S}, 043^{\circ} 24^{\prime} 47.17^{\prime \prime} \mathrm{W}\right)$. The vegetation in Canavarro consists mainly of Guinea grass, though Solanum paniculatum L., Solanum lycorcapum St. Hil., Cecropia sp. and Trema micanthra (L.) Blume are also present.

Area 3. This area, characterized by late secondary vegetation, was designated Bioreserve. It is within the reserve $\left(22^{\circ} 34^{\prime} 57.4^{\prime \prime} \mathrm{S}, 043^{\circ} 26^{\prime} 15.9^{\prime \prime} \mathrm{W}\right)$ and contains vegetation resulting from natural succession after total or partial suppression of the primary vegetation by human intervention or natural causes. It contains an arboreal stratum with Ficus spp. and an understory with predominance of Piper spp. The sampling points were located near the banks of Tinguá River and nearby watercourses, just outside the reserve's administrative building, on a trail starting at a workers' lodging (CEDAE's, the state

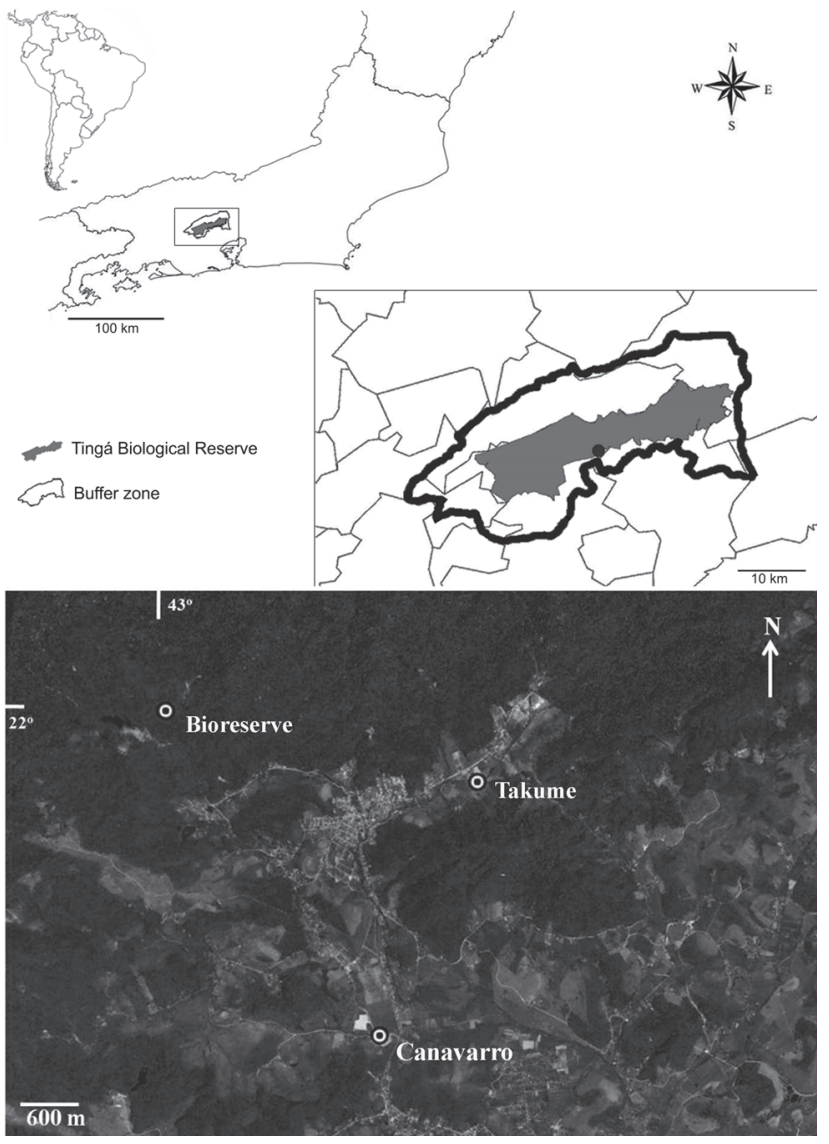

Figure 1. Location of the buffer zone and Tinguá Biological Reserve, state of Rio de Janeiro, with satellite image (Google Earth: April 22, 2011) indication of the sampling areas.

water and sewer company) at the Macuco Dam, where there are banana, cajá and lemon (Citrus limonum Risso) trees.

Sampling was conducted monthly, one night in each of the areas, on consecutive days, totaling three nights per month and 72 nights in two years, from May 2011 to April 2013. Bats were captured with mist nets (usually ten mist nets measuring $12 \times 3 \mathrm{~m}$ and $20 \mathrm{~mm}$ mesh) extended at ground level, which were opened at dusk and closed just after dawn. Sampling was performed regardless of the weather. The nets were placed in open areas, in the understory, on river banks and over water.

Bats were identified in the field using the descriptions of Vizotto \& Taddei (1973), Gardner (2007) and Dias \& Peracchi (2008), tagged with collars and then released. Some specimens that could not be definitely identified in the field were taken to the laboratory for confirmation and deposited in the Adriano Lucio Peracchi collection located at the Biology Institute of Federal Rural University of Rio de Janeiro, Seropédica, state of Rio de Janeiro (Appendix 1). These specimens were collected under license from SISBIO/ICMBio number 28064-2. 
The sampling effort was calculated according to STRAUBE $\&$ Bianconi (2002) and the Kruskal-Wallis test was used to assess possible differences in sampling effort between areas. The Margalef richness and Simpson diversity indices (1-D) and Pielou's evenness index were calculated for each area (MAGURRAN 2004). For pairwise comparison of the areas' ecological indices, randomized bootstrap was used.

The species accumulation curves (SOBERón \& Llorente 1993) for each area were plotted by randomization (100 iterations) based on the total number of captures and the first-order jackknife (Jackknife-1) estimator (Cowell \& Coddington 1994, Hellmann \& Fowler 1999) was calculated, both with the EstimateS software (Colwell 2009).

To assess whether there are differences in the composition of bat species between areas, the Kruskal-Wallis test was used. One-way analysis of similarity (ANOSIM) was also used to assess possible differences among the three bat assemblages studied. ANOSIM was based on the use of Bray-Curtis dissimilarity measures between samples (areas) and within samples (nights). This test produces an R-statistic that varies from - 1 to 1. The groups are considered to differ more as the statistic becomes more positive (Clarke 1993). Species turnover was represented using Whittaker's beta-diversity index and based on the presence/absence of each species in each area. The Chisquare test was applied to compare species abundance among the areas. Ecological indices were calculated and statistical analyses were performed with the PAST version 1.44 software (HAMmer et al. 2001).

\section{RESULTS}

The sampling effort was similar in the three areas $(\mathrm{H}=$ $1.139, \mathrm{p}=0.566$ ) and comprised a total of $268,473 \mathrm{~m}^{2 *} \mathrm{~h}$. Twentysix bat species were captured (Table I), with a significant difference in species richness between Takume and Bioreserve. The Bioreserve was the richest area, also presenting the greatest Margalef richness. The Simpson diversity index was significantly lower in the Canavarro area than in the other areas. In turn, Pielou's evenness index was higher in the Takume area than in the other two (Table II).

Species accumulation curves and Jackknife-1 estimator of species richness showed that richness was the highest in Takume. In Canavarro, the curve showed signs of leveling, while in the Bioreserve area the curve was ascending (Figs 2-5). In Canavarro, the richness found represented $85 \%$ of its estimated richness while in the Bioreserve this value was 73\% (Table II). The addition of species occurred until the 10th sampling night $(36,150$ $\mathrm{m}^{2 *} \mathrm{~h}-141$ individuals captured) in the Takume area, until the $19^{\text {th }}$ in Canavarro $\left(71,337 \mathrm{~m}^{2 *} \mathrm{~h}-527\right.$ individuals) and until the $18^{\text {th }}$ in the Bioreserve $\left(70,353 \mathrm{~m}^{2 *} \mathrm{~h}-301\right.$ individuals).

The three areas differed in their composition of assemblages $(H=6.206, p=0.045)$ due to differentiation between the Bioreserve and Takume $(\mathrm{p}=0.017)$. The analysis of similar-
Table I. Number of bats captured in the buffer zone and Tinguá Biological Reserve, state of Rio de Janeiro. ${ }^{a}, b, c$ Difference between abundance of two areas $\left(x^{2}>3.84, p<0.05\right)$. ${ }^{\text {a Takume }} x$ Canavarro, ${ }^{b} T a k u m e \times$ Bioreserve, ${ }^{\mathrm{C} C}$ Canavarro $\mathrm{x}$ Bioreserve. (Tak) Takume, (Can) Canavarro, (Bio) Bioreserve.

\begin{tabular}{|c|c|c|c|c|}
\hline Taxa & Tak & Can & Bio & Total \\
\hline \multicolumn{5}{|l|}{ Phyllostomidae } \\
\hline \multicolumn{5}{|l|}{ Desmodontinae } \\
\hline Desmodus rotundus (É. Geoffroy, 1810) a, b, c & 34 & 5 & 1 & 40 \\
\hline Diphylla ecaudata Spix, $1823^{c}$ & 4 & 5 & - & 9 \\
\hline \multicolumn{5}{|l|}{ Glossophaginae } \\
\hline Anoura caudifer (É. Geoffroy, 1818) & 3 & 2 & 5 & 10 \\
\hline Anoura geoffroyi Gray, 1838 & - & 2 & 1 & 3 \\
\hline Glossophaga soricina (Pallas, 1766) ${ }^{\mathrm{a}, \mathrm{b}, \mathrm{c}}$ & 28 & 4 & 1 & 33 \\
\hline Lonchophylla peracchii Dias et al., 2013 & - & - & 1 & 1 \\
\hline \multicolumn{5}{|l|}{ Phyllostominae } \\
\hline Chrotopterus auritus (Peters, 1856) & - & 1 & - & 1 \\
\hline Micronycteris hirsuta (Peters, 1869) & - & - & 1 & 1 \\
\hline Micronycteris minuta (Gervais, 1856) & - & - & 1 & 1 \\
\hline Phylloderma stenops Peters, 1865 & - & - & 1 & 1 \\
\hline Phyllostomus hastatus (Pallas, 1767) $\mathrm{a}, \mathrm{b}, \mathrm{c}$ & 8 & - & 1 & 9 \\
\hline Tonatia bidens (Spix, 1823) b,c & - & - & 3 & 3 \\
\hline \multicolumn{5}{|l|}{ Carolliinae } \\
\hline Carollia perspicillata (Linnaeus, 1758) a & 144 & 109 & 131 & 384 \\
\hline \multicolumn{5}{|l|}{ Stenodermatinae } \\
\hline Artibeus fimbriatus Gray, 1838 a,b, c & 9 & 31 & 41 & 81 \\
\hline Artibeus lituratus (Olfers, 1818) a, b, c & 120 & 201 & 93 & 414 \\
\hline Artibeus obscurus (Schinz,1821) a, b, c & 86 & 4 & 48 & 138 \\
\hline Artibeus planirostris (Spix, 1823) ${ }^{\mathrm{a}, \mathrm{b}, \mathrm{c}}$ & 5 & 5 & 35 & 45 \\
\hline Dermanura cinerea (Gervais, 1856) ${ }^{b, c}$ & - & - & 4 & 4 \\
\hline Chiroderma doriae Thomas, 1891 & - & 1 & - & 1 \\
\hline Chiroderma villosum Peters, 1860 & - & - & 1 & 1 \\
\hline Platyrrhinus lineatus (É. Geoffroy, 1810) b, c & 7 & 7 & - & 14 \\
\hline Platyrrhinus recifinus (Thomas, 1901) a, b, c & 23 & 9 & 4 & 56 \\
\hline Pygoderma bilabiatum (Wagner, 1843) & 3 & 1 & 3 & 7 \\
\hline Sturnira lilium (É. Geoffroy, 1810) ${ }^{a, b, c}$ & 14 & 224 & 3 & 241 \\
\hline Vampyressa pusilla (Wagner, 1843) b,c & - & - & 4 & 4 \\
\hline \multicolumn{5}{|l|}{ Vespertilionidae } \\
\hline \multicolumn{5}{|l|}{ Myotinae } \\
\hline Myotis riparius Handley, 1960 & 2 & 1 & 4 & 7 \\
\hline Total & 489 & 623 & 399 & 1511 \\
\hline
\end{tabular}

ity showed a significant difference among the three areas $(\mathrm{R}=$ $0.292, \mathrm{p}<0.001$ ), although $\mathrm{R}$ was low, indicating low similarity between areas. Canavarro and Bioreserve differed the most ( $\mathrm{R}$ $=0.427)$, followed by Takume and Bioreserve $(\mathrm{R}=0.313)$ and lastly Canavarro and Takume $(\mathrm{R}=0.144)$. Whittaker's beta di- 

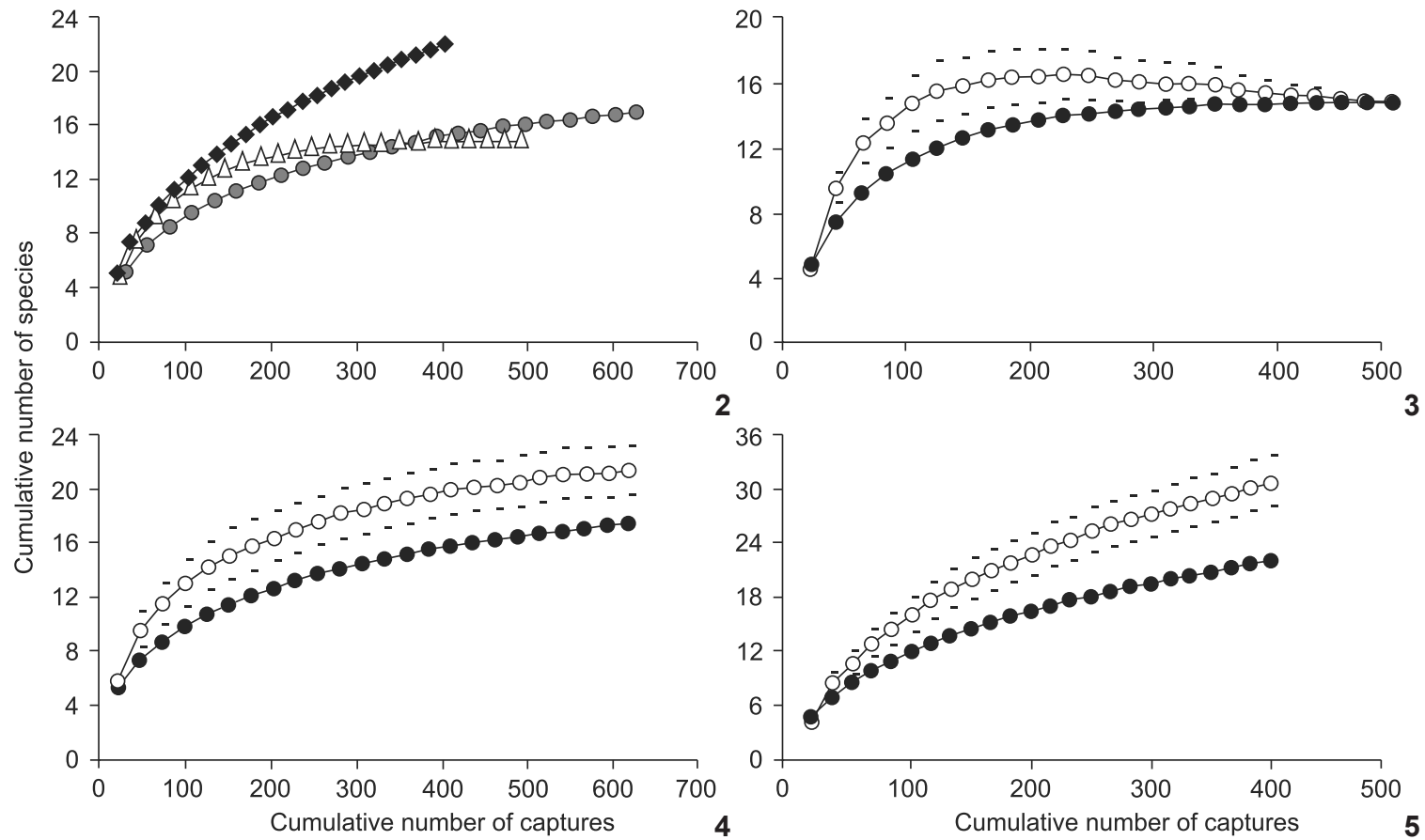

Figures 2-5. Randomized accumulation curves of bat species in the buffer zone and Tinguá Biological Reserve, state of Rio de Janeiro. (2) Bioreserve (black diamond), Canavarro (dark grey circle), Takume (light grey triangle); (3) Takume; (4) Canavarro; (5) Bioreserve: Sobs (Mao Tau) (black circle), Jackknife-1 estimator (empty circle), standard deviation (trace).

Table II. Sampling effort and ecological index in the areas of the buffer zone and Tinguá Biological Reserve, state of Rio de Janeiro.

\begin{tabular}{lcccc}
\hline & Takume & Canavarro & Bioreserve & Total \\
\hline Richness & 15 & 17 & 22 & 26 \\
Sampling effort $\left(\mathrm{m}^{2 *} \mathrm{~h}\right)$ & 89,295 & 86,898 & 92,280 & 268,473 \\
Jackknife 1st-order estimator & 15 & 20.83 & 30.62 & 28.66 \\
(Confidence interval 95\%) & $(15-15)$ & $(19.05-22.61)$ & $(27.92-33.32)$ & $(26.01-31.30)$ \\
Margalef richness & 2.26 & 2.48 & 3.50 & 3.41 \\
(Bootstrap 95\% Confidence) & $(2.42-3.39)$ & $(2.49-3.42)$ & $(2.34-3.51)$ & $(2.73-3.41)$ \\
Simpson diversity (1-D) & 0.81 & 0.74 & 0.78 & 0.82 \\
(Bootstrap 95\% Confidence) & $(0.79-0.83)$ & $(0.80-0.83)$ & $(0.79-0.83)$ & $(0.80-0.83)$ \\
Pielou's eveness & 0.73 & 0.58 & 0.62 & 0.63 \\
(Bootstrap 95\% Confidence) & $(0.65-0.73)$ & $(0.64-0.71)$ & $(0.66-0.74)$ & $(0.63-0.68)$ \\
\hline
\end{tabular}

versity index was highest between Canavarro and Bioreserve (0.33), followed by the Takume and Bioreserve (0.30) and lastly Takume and Canavarro (0.12). The Bioreserve contributed $84.61 \%$ to the regional richness.

The total number of specimens captured was 1,511, ranging from 399 to 623 specimens in each area, with significant differences among areas. The most abundant species in the entire region was Artibeus lituratus (Olfers, 1818) (27.53\%), followed by Carollia perspicillata (Linnaeus, 1758) (25.41\%) and Sturnira lilium (É. Geoffroy, 1810) (15.95\%). The dominant spe- cies in each area were S. lilium (35.95\%) in Canavarro and C. perspicillata in Takume (29.45\%) and Bioreserve (32.83\%). The Bioreserve had eight exclusive species, Canavarro had two and Takume had none. Seven species were represented by only one individual in the samples, five of them in the Bioreserve and two in Canavarro. With one exception, Myotis riparius Handley, 1960, (Vespertilionidae) all captured species belong to the family Phyllostomidae. There was a difference in the abundance of some species among the three areas (Table I). This difference was significant for nine species. 


\section{DISCUSSION}

The riparian forests studied showed high richness and abundance of bats, as reported in some other studies (FLEMING et al. 1972, Bordignon 2006, Cruz et al. 2007, CAMARgo et al. 2009, Arriaga-Flores et al. 2012). Likewise, the composition of bat species followed the same pattern found in other Neotropical areas, with the predominance of Phyllostomidae, a few dominant species and many rare species (Estrada et al. 1993, Stevens \& Willig 2002, Zanon \& Reis 2007, Bobrowiec \& Gribel 2010, Arriaga-Flores et al. 2012).

The results of this study emphasize the relevance of these environments to bats of the family Phyllostomidae. This family has the largest number of species in the Neotropics, and includes species with varied feeding habits and many frugivorous species (GARDNER 2007), which were prevalent in our samples (see KALKO et al. 1996). The few studies focusing on riparian forest areas in the Neotropics have found high abundance and richness of frugivorous and insectivorous bats (CAMARGO et al. 2009, LOURENÇO et al. 2010a, b, Galindo-Gonzales \& Sosa 2003, Arriaga-Flores et al. 2012). The high richness and abundance of insectivorous bats in these environments is mainly related to the availability of water resources and the abundance of insects (Lourenço et al. 2010a, b, Costa et al. 2012). The richness of insectivores can vary according to the presence or absence of vegetation cover (Costa et al. 2012), while frugivorous species are more associated with the surrounding vegetation (GALINDO-GonzalEs \& Sosa 2003, Avila-Cabadilla et al. 2012). Although our sampling method favored the capture of Phyllostomidae bats (Simmons \& Voss 1998), open nets over the water were not efficient in capturing insectivores of other families, such as Mollossidae and Vespertilionidae, as also demonstrated by other studies (LouREnço et al. 2010a,b, CosTA et al. 2012).

Our sampling strategy, including three areas of riparian forest that have different vegetation, serves to increase knowledge of the diversity of the region. The greater the variety of environments sampled, the greater the chances of finding species not previously recorded in a particular region (STEVENS \& Willig 2002, Bergallo et al. 2003). Although Takume and Canavarro are in permanent preservation areas of riparian forest, and also in the buffer zone of the reserve, the local richness of these areas contributed little to the regional richness, with the Bioreserve contributing the most.

This study added six new records to the list of bats found in the reserve: Artibeus planirostris (Spix, 1823), Micronycteris hirsuta (Peters, 1869), Micronycteris minuta (Gervais, 1856), Phylloderma stenops Peters, 1865, Phyllostomus hastatus (Pallas, 1767) and Chiroderma villosum Peters, 1960. Additionally, two other species, captured in the buffer zone of the Tinguá Biological Reserve, can be added to the list, Chiroderma doriae Thomas, 1891 and Chrotopterus auritus (Peters, 1856). This increases the number of bat species recorded for the conservation unit from 28 (Dias \& Peracchi 2008) to 36. Since bats tend to be better represented in riparian forest than in the surrounding areas, (Sherwin et al. 2000, Rogers et al. 2006, CAMARgo et al. 2009), our sampling strategy played a decisive role in finding the new records.

However, even though species richness in the Bioreserve was high, the highest diversity index obtained in this study was not for this area. This results from a number of species being represented by a few individuals and the high dominance of $C$. perspicillata. The highest diversity index was calculated for the Takume area, although it presented the lowest species richness. In Canavarro, dominance was also high, with most individuals belonging to only three species.

It is noteworthy that among the three areas, Takume was the only one that was detected in the accumulation curve stabilization and reached the maximum number of species according to the Jackknife- 1 estimator. This probably results from the agricultural use of this area, which does not attract some bat species and mainly favors those that are adapted to anthropogenic environments, such as $A$. lituratus and $C$. perspicillata (Bonnacorso \& Gush 1987, Estrada \& Coates-Estrada 2002, Gallo et al. 2008). In the Bioreserve, the Jackknife-1 estimated 30 species, but this number is underestimated in relation to the richness now known, 34 species according to Dias $\&$ Peracchi (2008) and this study.

The differences in the assemblages of bats between areas were expected, especially between the agricultural area and the Bioreserve. The beta diversity between the areas reveals the specificity of habitats in the Bioreserve and a possible limitation on the dispersion of some species. When we analyzed the species composition between this and the other areas, it appeared that some species found exclusively in the Bioreserve are more strongly associated with preserved areas, as it is the case of species in the subfamily Phyllostominae (Fenton et al. 1992, Medellín et al. 2000, Bobrowiec \& Gribel 2010). Species such as $M$. hirsuta and $P$. stenops have low density in Atlantic Forest areas (Reis et al. 2007, SAmpaio et al. 2008a, b, Peracchi \& Nogueira 2010), which explains their low abundance in our data. These two species had only been previously recorded twice in the state (Peracchi \& Albuquerque 1993, Esbérard 2004, EsbéraRd \& Faria 2006).

In Canavarro, we highlight the presence of $C$. doriae and C. auritus, both represented by a single individual. The occurrence of $C$. auritus in Canavarro was not expected, because it is more common in primary and secondary forests (PERACCHI \& Albuquerque 1993, Baptista \& Mello 2001, Bianconi et al. 2004), although it has also been recorded in open areas (Emmons \& Feer 1990, Gonçalves \& Gregorin 2004).

In Canavarro, the high abundance and dominance of $A$. lituratus and S. lilium can be explained by the presence of $S$. lycocarpum, a solanaceous species (Solanaceae) that is one of the first to colonize anthropogenic environments. It bears fruit almost throughout the year (Moura et al. 2010), and has been listed as a food resource for these bats (FABÍn et al. 2008, per- 
sonal observation). ZANON \& ReIs (2007) observed large consumption of solanaceous species by A. lituratus and S. lilium in the state of Paraná. The presence of these bat species attracted to this key species can bring benefits to the successional process, as it can lead to dispersal of seeds to other areas, aiding in their restoration (Kunz et al. 2011).

In Takume, the presence of guava fruits throughout the year may have influenced the dominance of $A$. lituratus and $C$. perspicillata. Both species are found in abundance in different biomes of the Neotropics (ReIs et al. 2000, SiMmons 2005, EsbÉRARD et al. 2006, Gardner 2007, Zanon \& Reis 2007, Bobrowiec \& Gribel 2010) and have more generalist feeding habits, explaining their occurrence in a variety of environments. These species are considered to be well adapted to human disturbances (BONNACORSO \& Gush 1987, Estrada \& Coates-Estrada 2002, Gallo et al. 2008) and cultivated fruit trees (Bernard et al. 2001, Kalko \& HandLEY 2001, Rex et al. 2008), such as guava in this study. Another species captured in abundance in Takume was D. rotundus. This may be associated with the proximity of cattle and horses, which are food resources for these bats, and a forest fragment that can provide shelter (GOMEs \& UIEDA 2004, Costa \& EsBÉRARD 2011). This result is consistent with the literature citing $D$. rotundus as a species commonly found in disturbed habitats (Fenton et al. 1992, Medellín et al. 2000, Costa \& Esbérard 2011). Among the species that were found in these three areas, $C$. perspicillata also stands out for its high abundance in all areas, demonstrating its plasticity (Bobrowiec \& GRIBEL 2010).

The variations in the assemblages of bats, such as richness, abundance, composition and diversity of species, in the three areas sampled demonstrate the impact of human disturbance and transformation of the riparian forest buffer zone of the Tinguá Biological Reserve. The different structures of riparian forests in the Tinguá region affected bat assemblages, although the expectation that the Bioreserve would have the highest ecological indices was not borne out. The Bioreserve did not have the greatest abundance of bats or the highest diversity index, but did have the highest richness and highest value of the Margalef richness index, as expected. Analysis of the composition and structure of its assemblage shows the importance of this area for some species and their relationship with the more preserved areas, emphasizing the importance of the area.

The higher rates of beta diversity of the Bioreserve in comparison with the other areas are indicative of two issues: the possibility of isolation of some populations of bats in the reserve and the ineffective protection of riparian forests. The areas studied are among those with the highest anthropogenic pressure in the reserve's buffer zone (MMA 2006). Therefore, measures are needed to minimize the impacts of this anthropization and allow riparian forests to exercise their role as ecological corridors for greater dispersion of species. Since riparian forests are already degraded, the commitment to reforestation and restoration is important and bats can accelerate this process through their ecological role as seed dispersers.

\section{ACKNOWLEDGMENTS}

We thank Entidade Ambientalista Onda Verde, particularly the staff members Rafael Dellamare and Hercides França $\mathrm{Jr}$; the staff of the Tinguá Biological Reserve, particularly the director, Flávio Silva; SINDIPETRO Caxias, particularly Carlinho Silva, and the directors Simão Zanardi Filho and Nivaldo A.S.O. Gomes; Paulo César Ribeiro for lodging and for logistic support; Mário Takume and the owner of the Canavarro area for his hospitality and permission to sample in his property; Renan M. Dias, Bruno Silva, and Camilla Mathias for field assistance; and Luciana M. Costa for review and criticism of an earlier version of this manuscript. We also thank the Brazilian agencies FAPERJ for financial support (E-26/111.364/2011), CNPq for the scholarships awarded to Elizabete C. Lourenço and Priscilla M.P. Patrício; and CAPES for the scholarships awarded to Michele C. Pinheiro and Luiz A.C. Gomes.

\section{LITERATURE CITED}

Arriaga-Flores, J.C.; I. Castro-Arellano; A. Moreno-Valdez \& A. Correa-SANDOVAL. 2012. Temporal niche overlap of a riparian Forest bat assemble in subtropical Mexico. Revista Mexicana de Mastozoología Nueva época 2: 26-20.

Avila-Cabadilla, L.D.; G.A. Sanchez-Azofeifa; K.E. Stoner; M.Y. Alvarez-Anorve; M. Quesada \& C.A. Portillo-Quintero. 2012. Local and landscape factors determining occurrence of Phyllostomid bats in tropical secondary forests. Plos One 7 (4): e35228. doi:10.1371/journal.pone.0035228

Baptista, M. \& M.A.R. MelLo. 2001. Preliminary inventory of the bat species of the Poço das Antas Biological Reserve, RJ. Chiroptera Neotropical 7 (1-2): 133-135.

Bergallo, H.G.; C.E.L. Esbérard; M.A.R. Mello; V. Lins; R. MangOlin \& M. BAPTISTA. 2003. Bat species richness in Atlantic Forest: What is the minimum sampling effort? Biotropica 35 (2): 278-288.

Bernard, E.; A.L. Albernaz \& W.E. Magnusson. 2001. Bat species composition in three localities in the Amazon Basin. Studies on Neotropical Fauna and Environment 36 (3): 177-184. doi: 10.1076/snfe.36.3.177.2125

Bianconi, G. V.; B.S. Мiкich \& W.A. Pedro. 2004. Diversidade de morcegos (Mammalia, Chiroptera) em remanescentes florestais do município de Fênix, noroeste do Paraná, Brasil. Revista Brasileira de Zoologia 21 (4): 943-954. doi:10.1590/ S0101-81752004000400032

Bobrowiec, P. \& R. Gribel. 2010. Effects of different secondary vegetation types on bat community composition in Central Amazonia, Brazil. Animal Conservation 13: 204-216. doi: 10.1111/j.1469-1795.2009.00322.x

Bonaccorso, F.J. \& T.J. Gush. 1987. Feeding behaviour and foraging strategies of captive phyllostomid fruit bats: an experimental study. Journal Animal Ecology 56: 907-920. Bordignon, M.O. 2006. Diversidade de morcegos (Mammalia, 
Chiroptera) do Complexo Aporé-Sucuriú, Mato Grosso do Sul, Brasil. Revista Brasileira de Zoologia 23 (4): 1002-1009. doi: 10.1590/S0101-81752006000400004

Camargo, G.; E. Fischer; F. Gonçalves; G. Fernandes \& S. Ferreira. 2009. Morcegos do Parque Nacional da Serra da Bodoquena, Mato Grosso do Sul, Brasil. Chiroptera Neotropical 15 (1): 417-424. doi: 10.1111/j.0030-1299.2004.12884.x

Cardoso-Leite, E.; T.B. Covre; R.G. Ometto; D.C. Cavalcanti \& M.I. Pagani. 2004. Fitossociologia e caracterização sucessional de um fragmento de Mata Ciliar, em Rio Claro, SP, como subsídio à recuperação da área. Revista do Instituto Florestal 16: 31-41. doi: 10.1590/S0100-67622008000300019

ClARKE, K.R. 1993. Non-parametric multivariate analysis of changes in community structure. Australian Journal Ecology 18: 117143. doi: 10.1111/j.1442-9993.1993.tb00438.x

ColWELL, R.K. 2009. Estimates: Statistical estimation of species richness and shared species from samples. Available online at: http://viceroy. eeb.uconn.edu/EstimateS. [Accessed: 16/VI/2012]

Colwell, R.K. \& J.A. Coddington. 1994. Estimating terrestrial biodiversity through extrapolation. Philosophical Transactions. Biological Series 345 (1311): 101-118. doi:10.1098/rstb.1994.0091

Costa, L.M. \& C.E.L. Esbérard. 2011. Desmodus rotundus (Mammalia: Chiroptera) on the southern coast of Rio de Janeiro state, Brazil. Brazilian Journal Biology 71: 1-8. doi: 10.1590/S1519-69842011000400020

Costa, L.M.; E.C. Lourenço; J.L. Luz; A.P.F. Carvalho \& C.E.L. EsBERARD. 2011. Activity of two species of free-tailed bats over a stream in southeastern Brazil. Acta Chiropterologica 13 (2): 405-409. doi: 10.3161/150811011X624884

Costa, L.M.; J.L. Luz \& C.E.L. Esbérard. 2012. Riqueza de morcegos insetívoros em lagoas no Estado do Rio de Janeiro, Brasil. Papéis Avulsos de Zoologia 52: 7-19. doi: 10.1590/ S0031-10492012000200001

Cruz, L.D.; C. Martinez \& F.R. Fernandes. 2007. Comunidades de morcegos em habitats de uma Mata Amazônica remanescente na Ilha de São Luís, Maranhão. Acta Amazônica 37 (4): 613-620.

Dias, D. \& A.L. Peracchi. 2008. Quirópteros da Reserva Biológica do Tinguá, Estado do Rio de Janeiro, sudeste do Brasil (Mammalia: Chiroptera). Revista Brasileira de Zoologia 25 (2): 333-369.

EMmons, L.H. \& F. Feer. 1990. Neotropical Rainforest Mammals: A field guide. Chicago, The University of Chicago Press, 307p.

Esbérard, C.E.L. 2004. Novo registro de Micronycteris hirsuta (Peters) (Mammalia, Chiroptera) na Mata Atlântica, Estado do Rio de Janeiro, Brasil. Revista Brasileira de Zoologia 21: 403-404. doi: 10.1590/S0101-81752004000200040

Esbérard, C.E.L. \& D. Faria. 2006. New records of Phylloderma stenops Peters, 1865 in the Atlantic Forest, Brazil (Chiroptera, Phyllostomidae). Biota Neotropica 6 (2). doi: 10.1590/ S1676-06032006000200026
Esbérard, C.E.L.; T. JordÃo-Nogueira; J.L. Luz; G.G.S. Melo; R. Mangolim; N. Jucá; D.S.L. Raíces; M.C. Enrici \& H.G. Bergallo. 2006. Morcegos da Ilha Grande, Angra dos Reis, RJ, Sudeste do Brasil. Revista Brasileira de Zoociências 8: 147-153.

Estrada, A. \& R. Coates-Estrada. 2002. Bats in continuous forest, forest fragments and in an agricultural mosaic habitat-island at Los Tuxtlas, Mexico. Biological Conservation 103 (3): 237-245. doi: 10.1016/S0006-3207(01)00135-5

Estrada, A.; R. Coates-estrada \& D.J.R. Meritt. 1993. Bat species richness and abundance in tropical rain forest fragments and in agricultural habitats at Los Tuxtlas, Mexico. Ecography 16 (4): 309-318. doi: 10.1111/j.1600-0587.1993.tb00220.x

Fabián, M.E.; A.M. Rui \& J.L. Waechter. 2008. Plantas utilizadas como alimento por morcegos (Chiroptera, Phyllostomidae), no Brasil, p. 51-70. In: N.R. ReIs.; A.L. Peracchi \& G.A.S.D. SANTOS (Eds). Ecologia de morcegos. Londrina, Technical Books, 148p.

Fenton, M.B. 1997. Science and the conservation of bats. Journal of Mammalogy 78: 1-15.

Fenton, M.B.; L. Acharya; D. Audet; M.B.C. Hickey; C. Merriman; M.K. Obrist; D. M. Syme \& B. Adkins. 1992. Phyllostomid bats (Chiroptera: Phyllostomidae) as indicators of habitat disruption in the Neotropics. Biotropica 24: 440-446.

Fleming, T.H.; E.T. Hooper \& D.E. Wilson. 1972. Three Central American bay communities: structure, reproductive cycle and movement patterns. Ecology 53: 553-569.

Galindo-GonzÁlez, J. \& V.J. Sosa. 2003. Frugivorous bats in isolated trees and riparian vegetation associated with human-made pastures in a fragmented tropical landscape. The Southwestern Naturalist 48 (4): 579-589. doi: 10.1894/ 0038 4909(2003)048<0579:FBIITA >2.0.CO;2

Gallo, P.H.; N.R. Reis; F.R Andrade \& I.G. Almeida. 2008. Morcegos (Mammalia, Chiroptera) encontrados em fragmentos de mata nativa e reflorestamento no Município de Rancho Alegre - Paraná, p. 97-107. In: N.R. Reis.; A.L. Peracchi \& G.A.S.D. SAntos (Eds). Ecologia de morcegos. Londrina, Technical Books, 148p.

Gardner, A.L. 2007. Order Chiroptera, p. 187-484. In: A.L. GARDNER (Ed.). Mammals of South America: Marsupials, Xenarthrans, Shrews, and Bats. London, Chicago and The University of Chicago press, vol. 1, 690p.

Gomes, M.N. \& W. Uieda. 2004. Abrigos diurnos, composição de colônias, dimorfismo sexual e reprodução do morcego hematófago Desmodus rotundus (E. Geoffroy) (Chiroptera, Phyllostomidae) no Estado de São Paulo, Brasil. Revista Brasileira de Zoologia 21 (3): 629-638. doi: 10.1590/S010181752004000300025

Gonçalves, E \& R. Gregorin. 2004. Quirópteros da Estação Ecológica da Serra das Araras, Mato Grosso, Brasil, com o primeiro registro de Artibeus gnomus e A. anderseni para o cerrado. Lundiana 5 (2): 143-149.

Hammer, O.; D.A.T. Harper \& P.D. Rian. 2001. Past: Palaeonthological statistics software package for education and data analysis. 
Version. 1.37. Available online at: http://palaeo-electronica.org/ 2001_1/past/issue1_01.htm. [Accessed:20/VII/2012]

Hellmann, J.J. \& G.W. Fowler. 1999. Bias, precision and accuracy of four measures of species richness. Ecological Application 9 (3): 824-834. doi: 10.1890/1051-0761(1999)009[0824: BPAAOF]2.0.CO;2

HollowaY, G.L. \& R.M.R. BARClay. 2000. Importance of prairie riparian zones to bats in southeastern Alberta. Ecoscience 7 (2): 115-122.

Kalko, E.K.V. \& C.O. Handley. 2001. Neotropical bats in the canopy: diversity community structure, and implications for conservation. Plant Ecology 153 (1-2): 319-333. doi: 10.1023/A:1017590007861

Kalko, E.K.V.; G.O. Handley \& D. Handley. 1996. Organization, diversity, and long-term dynamics of a neotropical bat community, p.503-553. In: M.L. Cody \& J.A. SMAllwood (Eds.). Long term studies in vertebrate communities. San Diego, Academic Press, 597p.

Kunz, T.H.; E.B. Torrez; D. Bauer; T. Lobova \& T.H. Fleming. 2011. Ecosystem services provided by bats. Annals of the New York Academy of Sciences 1223 (1): 1-38. doi: 10.1111/ j.1749-6632.2011.06004.x

LiMA, W.P. \& M.J.B. ZAKIA. 2001. Hidrologia de matas ciliares, p. 33-44. In: R.R. Rodrigues \& H.F. Leitão-Filho (Eds). Matas ciliares: conservação e recuperação. São Paulo, Edusp/ Fapesp, 320p.

Lourenço, E.C.; L.M. Costa; J.L. Luz; R.M. Dias \& C.E.L. Esbérard. 2010a. Morcegos em manguezal - análise de uma assembléia e compilação de dados disponíveis no Brasil, p. 173187. In: L.M. Pessoa; W.C. Tavares \& S. Siciliano (Eds). Mamíferos de restingas e manguezais do Brasil. Rio de Janeiro, Sociedade Brasileira de Mastozoologia, 282p.

Lourenço, E.C.; L.M. Costa; R.M. Silva \& C.E.L. Esbérard. 2010b. Bat diversity of Ilha da Marambaia, Southern Rio de Janeiro State, Brazil (Chiroptera, Mammalia). Brazilian Journal of Biology 70 (3): 511-519. doi: 10.1590/S1519-69842010000300007

MagurRan, A.E. 2004. Measuring biological diversity. Oxford, Blackwell Science, 256p.

Martins, S.V. 2001. Recuperação de matas ciliares. Viçosa, Editora Aprenda Fácil, 225p.

Medellín, R.A.; M. Equihua \& M.A. Amin. 2000. Bat diversity and abundance as indicators of disturbance in Neotropical rainforests. Conservation Biology 14: 1666-1675. doi: 10.1111/j.1523-1739.2000.99068.x

MMA. 2006. Plano de Manejo da Reserva Biológica do Tinguá. Brasília, Bourscheid S.A. Engenharia e Meio Ambiente, Ecomek Consultoria Empresarial e Meio Ambiente, 951p.

Moura, T.M.; G.X.O. Oliveira \& L.J. Chaves. 2010. Correlação entre floração, frutificação e variáveis ambientais em Solanum lycocarpum A. St. Hil, Solanaceae. Bioscience Journal 26: 457-462.

Odum, E.P. \&. G.W. Barrett. 2006. Fundamentos de Ecologia. São Paulo, Thomson Learning, 612p.
Peracchi, A.L. \& S.T. Albuquerque. 1993. Quirópteros do Município de Linhares, Estado do Espírito Santo, Brasil (Mammalia: Chiroptera). Brazilian Journal Biology 53: 575-581.

Peracchi, A.L. \& M.R. Nogueira. 2010. Lista anotada dos morcegos do Estado do Rio de Janeiro, sudeste do Brasil. Chiroptera Neotropical 16: 508-519.

Reis, N.R.; A.L. Peracchi; I.P. Lima \& W.A. Pedro. 2006. Riqueza de espécie de morcegos (Mammalia, Chiroptera) em dois diferentes habitats, na região centro-sul do Paraná, sul do Brasil. Revista Brasileira de Zoologia 23 (3): 813-816.

Reis, N.R.; A.L. Peracchi; M.L. Sekiama \& I.P. Lima. 2000. Diversidade de morcegos (Chiroptera, Mammalia) em fragmentos florestais no estado do Paraná, Brasil. Revista Brasileira Zoologia 17: 697-704.

Reis, N.R.; A.L. Peracchi; W.A. Pedro \& I.P. Lima. 2007. Morcegos do Brasil. Londrina, Universidade Estadual de Londrina, 253p.

ReX, K.; D.H. Kelm; K. Wiesner; T.H. Kunz \& C.C. Voigt. 2008. Species richness and structure of three Neotropical bat assemblages. Biological Journal of the Linnean Society 94: 617-629. doi:10.1111/j.1095-8312.2008.01014.x

Rogers, D.S.; M.C. Belk; M.W. Gonzalez \& B.L. Coleman. 2006. Patterns of habitat use by bats along a riparian corridor in northern Utah. Southwestern Naturalist 51: 52-58. doi: 10.1894/0038-4909(2006)51[52:POHUBB]2.0.CO;2

Sampaio, E.; B. Lim; S. Peters \& J. Arroyo-Cabrales. 2008 a. Phylloderma stenops. In: IUCN 2012. IUCN Red List of Threatened Species. Version 2012.2. Available online at: http://www.iucnredlist.org [Accessed: 07/I/2013]

Sampaio, E.; B. Lim; S. Peters \& W. Pineda. 2008b. Micronycteris minuta. In: IUCN Red List of Threatened Species. Version 2012.2. Available online at: http://www.iucnredlist.org. [Accessed: 11/XII/2012]

Sherwin, R.E.; W.L. Gannon \& S. Haymond. 2000. The efficacy of acoustical techniques to infer differential use of habitat by bats. Acta Chiropterologica 2: 145-153.

Simmons, N.B. 2005. Order Chiroptera, p. 312-529. In: D.E. WILSON \& D.M. REEDER (Eds). Mammal species of the world: a taxonomic and geographic reference. Washington, D.C., Smithsonian Institution Press, 2000p.

Simmons, N.B. \& R.S. Voss. 1998. The mammals of Paracou, French Guiana: a Neotropical lowdland rainforest fauna. Bulletin of the American Museum of Natural History 237: 1-219.

Soberón, J. \& J. Llorente. 1993. The use of species accumulation functions for the prediction of species richness. Conservation Biology 7: 480-488.

Stevens, R.D. \& M.R. Willig. 2002. Geographical ecology at the community level: perspectives on the diversity of new world bats. Ecology 83: 545-560. doi: 10.1890/0012-9658(2002) 083[0545:GEATCL]2.0.CO;2

Straube, F.C. \& G.V. Bianconi. 2002. Sobre a grandeza e a unidade utilizada para estimar esforço de captura com utilização 
de redes de neblina. Chiroptera Neotropical 8: 150-152.

VizotTo, L.D. \& V.A. TAdDEI. 1973. Chave para a determinação dos quirópteros brasileiros. Faculdade Filosofia Ciências Letras São José do Rio Preto 1: 1-72.

Williams, J.A.; M.J. O'FARRELl \& B.R. RiddLE. 2006. Habitat use by bats in a riparian corridor of the Mojave desert in southern
Nevada. Journal of Mammalogy 87 (6): 1145-1153. doi: 10.1644/06-MAMM-A-085R2.1

Zanon, C.M.V. \& N.R. Reis. 2007. Bats (Mammalia, Chiroptera) in the Ponta Grossa region, Campos Gerais, Paraná, Brazil. Revista Brasileira de Zoologia 24 (2): 327-332. doi: 10.1590/S0101-81752007000200010

Appendix 1. Vouchers deposited in the Adriano Lúcio Peracchi collection, Biology Institute, Federal Rural University of Rio de Janeiro.

Anoura caudifer (Geoffroy, 1818) ALP 10359 male/ALP 10370 male, Artibeus lituratus (Olfers, 1818) ALP 10356 male, Artibeus obscurus Schinz, 1821 ALP 10361 male/ALP 10343 female, Artibeus planirostris (Spix, 1823) ALP 10355 male/ALP 10353 female/ALP 10364 female, Carollia perspicillata (Linnaeus, 1758) ALP 10338 male/ALP 10375 male/ALP 10347 female/ALP 10374 female, Chiroderma doriae (Thomas, 1891) ALP 10345 male, Chiroderma villosum Peters, 1860 ALP 10371 male, Chrotopterus auritus (Peters, 1856) ALP 10354 male, Dermanura cinerea (Gervais, 1856) ALP 10351 male/ALP 10352 female, Desmodus rotundus (É. Geoffroy, 1810) ALP 10341 male/ALP 10342 male, Diphylla ecaudata Spix, 1823 ALP 10363 male/ALP 10362 female, Glossophaga soricina (Pallas, 1766) ALP 10350 male, Lonchophylla peracchii Dias et al. 2013 ALP 10369 female, Micronycteris hirsuta (Peters, 1869) ALP 10358 male, Micronycteris minuta (Gervais 1856) ALP 10357 female, Myotis riparius Handley, 1960 ALP 10340 male/ALP 10360 female, Phylloderma stenops Peters, 1865 ALP 10365 male, Phyllostomus hastatus (Pallas, 1767) ALP 10367 male, Platyrrhinus recifinus (Thomas, 1901) ALP 10366 male, Pygoderma bilabiatum (Wagner, 1843) ALP 10344 male, Sturnira lilium (É. Geoffroy, 1810) ALP 10346 male/ALP 10349 male, Tonatia bidens (Spix, 1823) ALP 10373 male, Vampyressa pusilla (Wagner, 1843) ALP 10339 male.

Submitted: 20.VIII.2013; Accepted: 16.III.2014.

Editorial responsibility: Fernando de C. Passos 